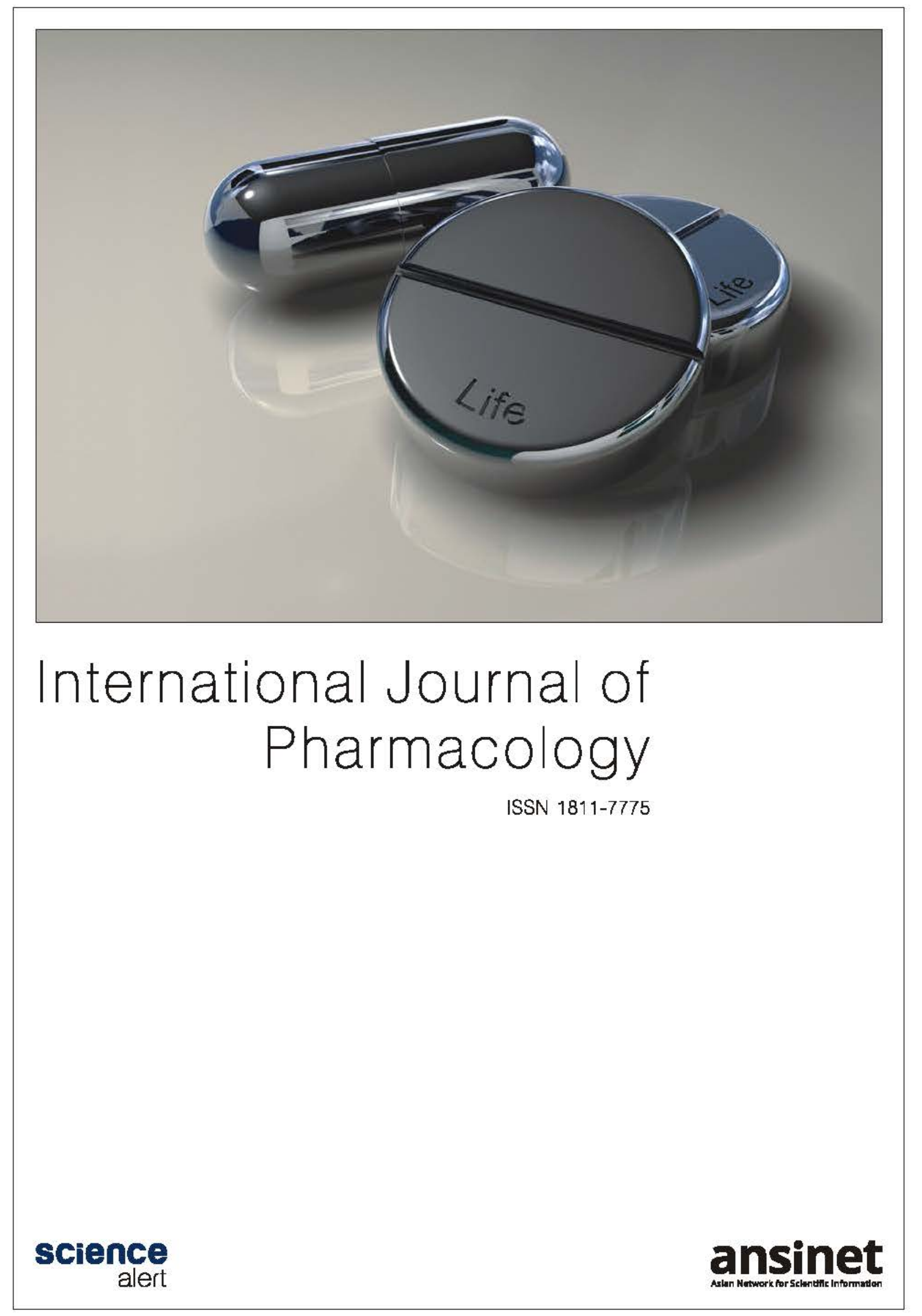


International Journal of Pharmacology 3 (2): 170-174, 2007

ISSN 1811-7775

(C) 2007 Asian Network for Scientific Information

\title{
Antibacterial Activity of Marine Bacterium Pseudomonas sp. Associated with Soft Coral Sinularia polydactyla against Streptococcus equi Subsp. zooepidemicus
}

\author{
${ }^{1,2}$ Ocky Karna Radjasa, ${ }^{3}$ Siti Isrina Oktavia Salasia, ${ }^{1,2}$ Agus Sabdono, ${ }^{4}$ Jutta Weise, \\ ${ }^{4}$ Johannes F. Imhoff, ${ }^{5}$ Christop Lämmler and ${ }^{6}$ Michael J. Risk \\ ${ }^{1}$ Department of Marine Science, Diponegoro University, Semarang, 50275, Central Java, Indonesia \\ ${ }^{2}$ Center for Tropical Coastal and Marine Studies, Diponegoro University, Widya Puraya, \\ Semarang, 50275, Central Java, Indonesia \\ ${ }^{3}$ Faculty of Veterinary Medicine, Gajah Mada University, Yogyakarta 55281, Indonesia \\ ${ }^{4}$ Leibniz-Institute of Marine Sciences (IFM-GEOMAR), 24105 Kiel, Germany \\ ${ }^{5}$ Institut für Pharmacologie und Toxicologie, Justus-Liebig-Universität Gießen, 35392, Gießen, Germany \\ ${ }^{6}$ School of Geography and Earth Sciences, McMaster University, Hamilton, ON, Canada
}

\begin{abstract}
A marine bacterium associated with soft coral Sinularia polydactyla collected from Bandengan water, Jepara, North Java Sea, Indonesia, was successfully screened for antibacterial activity against pathogenic bacterium Streptococcus equi subsp. zooepidemicus K6.72 isolated from infected monkey of the island of Bali and identified based on morphological, biochemical and molecular methods. Marine bacterium was identified as Pseudomonas sp. based on its 16S rDNA and was found to amplify gene fragments of Non-ribosomal peptide synthetase (NRPS). Cloning and subsequent sequencing, a 360 bp long DNA fragment was obtained and the deduced amino acid sequence showed conserved signature regions for peptide synthetases and revealed a high similarity of $61.1 \%$ to genes peptide synthetase of Bacillus subtilis.
\end{abstract}

Key words: Screening, soft coral-associated bacteria, secondary metabolites

\section{INTRODUCTION}

Soft corals are an important and diverse group of colonial invertebrates belonging to the Phylum Coelenterata (Cnidaria), Class Anthozoa, Subclass Octocorallia. One of the major groups, the order Alcyonacea consists of hundreds of different species including the member of Sinularia can dominate many Indo-Pacific reefs (de Nys et al., 1991). Furthermore, one of the reasons for the evolutionary success of the alcyonacean soft corals in the Indo-Pacific is considered to be the high level of secondary metabolites commonly found in their tissues (Sammarco and Coll, 1992). Thus, it has been the main reason for the searching of secondary metabolites with various biological activities from softcorals.

Among streptococcus, Streptococcus equi subsp. zooepidemicus has been known as the cause of infection of a wide variety of animals such as pigs, cows, goats and monkeys (Salasia et al., 2004), which resulted in the occurrence of pneumonia, meningitis and arthritis. Infections of streptococcus group C (SGC) have been reported from Mexico (Edwards et al., 1988) and the island of Bali, Indonesia (Salasia et al., 2004). Further, Bradley et al. (1991), reported that infection of SGC was caused by pathogenic Streptococcus zooepidemicus $(72.7 \%)$.

Bioactive-producing marine invertebrates, including softcorals are insufficient for producing commercial quantities of metabolites of interest. Therefore, a solution to overcome the problem of supply is needed. It has been widely reported that many bioactive natural products from marine invertebrates have striking similarities to metabolites of their associated microorgamisms including bacteria (Proksch et al., 2002; Thiel and Imhoff, 2003; Radjasa et al., 2007). Thus, it is important to highlight the possible role of marine bacteria associated with soft coral in providing solution to the problem of infection by pathogenic bacterium Streptococcus equi subsp. epidemicus. Bacteria-soft coral association that occurs on the soft coral surface then could be of great interest to search for potential use as new source of antibiotics.

Advanced techniques of molecular biology such as Polymerase Chain Reaction (PCR), in particular the application of degenerated primers of Non-ribosomal peptide synthetases (NRPS) to amplify gene fragments

Corresponding Author: Ocky Karna Radjasa, Department of Marine Science, Diponegoro University, Semarang, 50275, Central Java, Indonesia Tel: +62-24-7460038/7474698 Fax: +62-24-7460039, 7474698 
from peptide producers has allowed screening on the presence of non ribosomal peptides among secondary metabolite-producing microorgamisms (Marahiel et al., 1997; Radjasa and Sabdono, 2003; Radjasa et al., 2007).

In this study, we reported the potential of marine bacterium associated with soft coral Sinularia polydactyla for the production of secondary metabolites against pathogenic Streptococcus equi subsp. zooepidemicus K6.72 bacterium coupled with PCR basedscreening for the presence of non-ribosomal polypeptide synthetases.

\section{MATERIALS AND METHODS}

Sampling and isolation of soft coral-associated bacteria: Colonies of soft coral were collected from Bandengan water, Jepara, North Java, Indonesia by scuba diving from a depth of $5 \mathrm{~m}$. Upon collection soft coral colonies were put into sterile plastic bags (Whirl-Pak, Nasco, USA) and brought to Marine Station, Diponegoro University. The tissues were then rinsed with sterile seawater and scraped off with a sterile knife. The resultant tissues were serially diluted, spread on $1 / 2$ strength ZoBell $2216 \mathrm{E}$ marine agar medium and incubated at room temperature for $48 \mathrm{~h}$. On the basis of morphological features, colonies were randomly picked and purified by making streak plates (Madigan et al., 2000).

Isolation of Streptococcus equi subsp. zooepidemicus bacterium: Isolation was carried out at Faculty of Veterinary Medicine, Gajah Mada University, Yogyakarta, Indonesia. Bacterium K6.72 was isolated from infected monkey from the area of natural tourism forest of Alas Kedaton, Bali island. Blood Agar Plate (blood agar base ( $40 \mathrm{~g} \mathrm{~L}^{-1}$ ) which was then mixed with $7 \%$ defibrinated blood from goat) was used to grow the isolate.

Morphological and biochemical characterization of isolate K6.72: Gram and biochemical tests (glucose, lactose, manitol, alanine, arabinose, rafinose, maltose, arginine, sorbitol, inuline and hemolysis activity) were carried out according to a method previously described (Salasia et al., 2004). The reference strain Streptococcus equi subsp. zooepidemicus was obtained from Institut für Pharmacologie und Toxicologie, Justus-Liebig-Universität Gießen, Gießen, Germany.

Screening of soft coral bacteria with biological activity: Screening and antibacterial tests as well as molecular based-works were carried out at Marine Microbiology Laboratory, Diponegoro University, Semarang, Indonesia. To screen their biological activity, 5 bacterial isolates were tested against isolate K6.72. One hundred microliter culture of indicator microorganism in the logarithmic phase (ca. $10^{9}$ cells $\mathrm{mL}^{-1}$ ) was spread on to agar medium. Several paper disks ( $8 \mathrm{~mm}$; Advantec, Toyo Roshi, Ltd., Japan) containing $30 \mu \mathrm{L}$ of the coral bacterial strain were placed on the respective agar surface. The plates were then incubated at room temperature for $48 \mathrm{~h}$. Biological activity was defined by the formation of inhibition zones around the paper disk. Isolate showed biological activity against K6.72 was chosen for further screening based on PCR technique by using specific primers of Nonribosomal peptide synthetase (NRPS).

Antibacterial test: Inhibitory interaction test of isolate TASC.16 against pathogenic Streptococcus equi subsp. zooepidemicus K6.72 was performed by using the agar disk-diffusion method. One hundred microliter culture of target microorganism in the logarithmic phase (ca. $10^{9}$ cells $\mathrm{mL}^{-1}$ ) was spread on to agar medium. Three paper disks ( $8 \mathrm{~mm}$; Advantec, Toyo Roshi, Ltd, Japan) containing $30 \mu \mathrm{L}$ of the softcoral bacterial strain were placed on the respective agar surface. The plates were then incubated at room temperature for $48 \mathrm{~h}$. Antibacterial activity was defined according to Radjasa et al. (2007) by the formation of inhibition zones greater than $9 \mathrm{~mm}$ around the paper disk.

PCR-based screening of NRPS producing bacterial strains: Genomic DNA of secondary metabolite producing-strains for PCR analysis were obtained from cell materials taken from an agar plate, suspended in sterile water (Sigma, Germany) and subjected to five cycles of freeze $\left(-80^{\circ} \mathrm{C}\right)$ and thaw $\left(95^{\circ} \mathrm{C}\right)$. Non-ribosomal peptide sythetases (NRPS) primers were prepared in the Marine Microbiology, IFM-GEOMAR, Kiel, Germany. Amplification of peptide synthetase gene fragments was carried out with the NRPS degenerated primers as described by Radjasa et al. (2007).

PCR amplification and sequencing of 16S rRNA gene fragments: PCR amplification of partial 16S rRNA gene of marine bacterium TASC.16 and monkey isolate K6.72, purification of PCR products and subsequent sequencing analysis were performed according to the methods of Thiel and Imhoff (2003) and Salasia et al. (2001), respectively. The determined DNA sequences of strains were then compared for homology to the BLAST database.

Cloning and sequencing of (putative) peptide synthetase domain: The amplified PCR-products were purified using the High Pure PCR Product Purification Kit (Roche 
Diagnostics, Mannheim, Germany) following the manufacturers protocol. The Big Dye Terminator Cycle Sequencing Ready Reaction Kit (Applied Biosystems) was used for subsequent sequencing on an ABI 310 analyzer (Perkin Elmer Applied Biosystems, Foster City, USA).

\section{RESULTS}

Screening of softcoral bacteria with biological activity: Screening among 5 marine bacteria associated with softcoral Sinularia polydactyla by using test organism revealed that only one isolate, TASC.16 capable of inhibiting the growth of Streptococcus equi subsp. zooepidemicus, while the rest of isolates showed no activity.

Inhibitory interaction test: The measurement of inhibition zone as indicator of the antibacterial potential of isolate TASC.16 against pathogenic K6.72 is presented in the following Table 1 .

PCR-based screening: As shown in the Fig. 1, isolate TASC. 16 was capable of amplifying the gene fragments of Non-ribosomal peptide synthetases (NRPS) indicated by the presence of single band having similar height to the positive control of Pseudomonas fluorescens DSM 50117.

Microbiological characterization: The microbiological characterization (morphological and biochemical tests) is presented in the Table 2 .

Molecular identification: A comparison of the 16S rRNA gene sequence of isolate TASC.16 with sequences from GenBank demonstrated that this strain is most closely related with Pseudomonas sp. (accession number EF111238) with a homology of $98 \%$.

On the other hand, the pathogenic isolate K6.73 was found to be closely related to streptococcus equi subsp, zooepidemicus isolate 122 (Alber et al., 2005) with a homology of $98 \%$ (Acession number AJ715480).

Putative peptide synthetase sequence: Following cloning and subsequent sequencing, a $360 \mathrm{bp}$ long DNA fragment was obtained and the deduced amino acid sequence

Table 1: Antibacterial activity of softcoral isolate TASC.16 against pathogenic K6.72

\begin{tabular}{|c|c|c|c|c|}
\hline \multirow[b]{2}{*}{ Isolate } & \multicolumn{4}{|c|}{ Inhibition zone $(\mathrm{mm})$} \\
\hline & I & II & III & Average \\
\hline TASC 16 & 15.50 & 16.10 & 15.70 & 15.76 \\
\hline
\end{tabular}

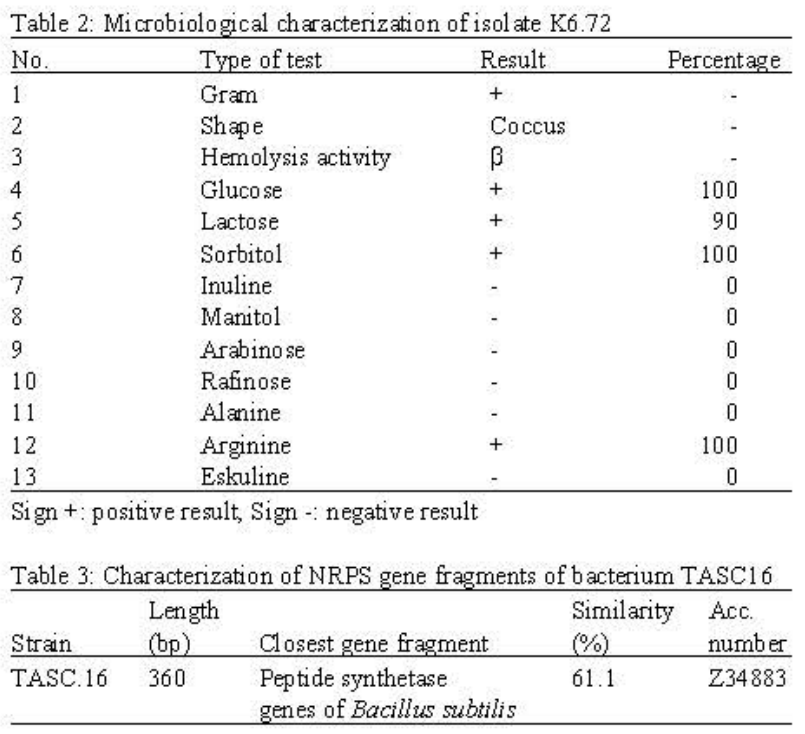

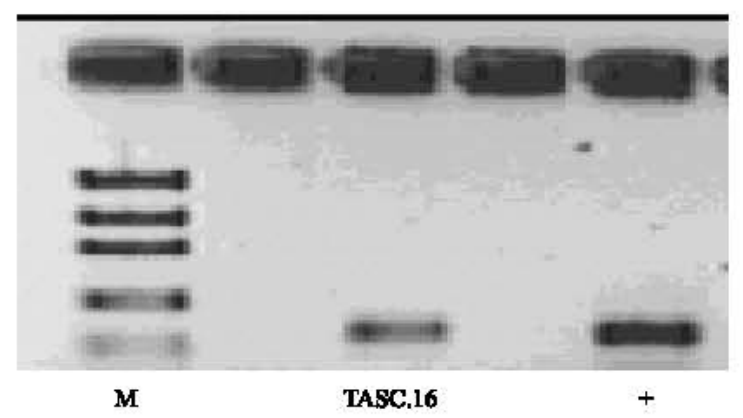

Fig. 1: PCR amplification of NRPS gene fragments; + control Pseudomonas fluorescens DSM No. 50117; $\mathrm{M}$ is DNA markers

showed conserved signature region for peptide synthetases and revealed a high similarity to genes of peptide synthetase of Bacillus subtilis (Table 3 ).

\section{DISCUSSION}

An attempt was carried out to estimate the potential of marine bacteria associated with soft coral Sinularia polydactyla as the source of antibacterial compounds in particular against the pathogenic streptococcus equi subsp. epidemicus.

Both microbiological and molecular-based methods confirmed that pathogenic bacterium $\mathrm{K} 6.72$ is Streptococcus equi subsp. zooepidemicus. This result is very similar to the occurrence of this bacterium during streptococcal outbreak in Bali island in 1994 (Sal asia et al., 2004) that infected pigs and monkeys from the same area of Alas Kedaton, Bali. Streptococcus equi subsp. zooepidemicus is well known as an important pathogen of 
the horse being associated with respiratory tract infections of foals and with uterine infections in mares (Salasia, 2001). In addition this bacterium can be isolated from infections of a wide variety of animals, including pigs, sheep, cows, goats, foxes, birds, rabbits, guinea pigs and monkeys. All of these ammals might be potential reservoirs for infections of humans.

It is interesting to note that softcoral bacterium Pseudomonas sp. TASC.16 showed strong growth inhibition against Streptococcus equi subsp. zooepidemicus K6.72. This raises the possibility the use of softcoral bacteria as the source of antibacterial compounds for controlling the pathogenic bacterium Streptococcus equi subsp. zooepidemicus. The members of genus Pseudomonas are well known to produce various peptide natural products including antibacterial (Mossialos et al., 2002), biosurfactants (Morikawa et al., 1993; Amada et al., 2000; Roongsang et al., 2003) and antifungals (Ramette et al., 2001; Nielsen et al., 2002; Sorensen et al., 2002).

Bacterium Pseudomonas sp. TASC.16 has also amplified the gene fragments of Non-ribosomal peptide sythetases (NRPS) that showed homology to the genes of peptide synthetases of Bacillus subtilis. The members of genus Bacillus were reported to produce also peptide natural products. Cereulide, the emetic toxin was putatively a product of non-ribosomal peptide synthesis of Bacillus cereus (Toh et al., 2004) which is known as the causative agent of two distinct types of toxinmediated food-borne illness, diarrhoel and emetic syndromes (Drobniewski, 1993). Furthermore, other Bacillus species, such as B. brevis, B. subtilis and $B$. licheniformis, produce cyclic peptides using nonribosomal peptide synthesis (Stachelhaus et al., 1995).

In conclusion, softcoral bacterium Pseudomonas sp. TASC. 16 capable of producing antibacterial compound as demonstrated by antibacterial test against pathogenic Streptococcus equi subsp zooepidemicus K6.72. It contained the NRPS gene fragment as shown by PCR screening. Further works are needed to clarify the responsible compounds in controlling the pathogenic strain tested.

\section{ACKNOWLEDGMENTS}

This study was partly supported by the grant from Indonesian Ministry of Research and Technology within Indonesian International Joint Research grant scheme (RUTI III) in the marine research area. The work was also part of a research grant provided by Lindbergh
Foundation, USA awarded to Ocky Karna Radjasa. Siti Isrina Oktavia Salasia and Ocky Karna Radjasa were research fellows of the Alexander von Humboldt Foundation (AvH), Germany.

\section{REFERENCES}

Alber, J., A. El-Sayed, S. Estoepangestie, C. Lammler and M. Zschock, 2005. Dissemination of the superantigen encoding genes seeL, seeM, szeL and szeM in Streptococcus equi subsp. equi and Streptococcus equi subsp. zooepidemicus. Vet. Microbiol., 109: 135-141.

Amada, K., M. Haruki, T. Imanaka, M. Morikawa and S. Kanaya, 2000. Overproduction in Escherichia coli, purification and characterization of a family I.3 lipase from Pseudomonas sp. MIS38. Biochim. Acta, 1487: 201-210.

Bradley, S.F., J.J. Gordon, D.D. Baumgartner, W.A. Marasco and C.A. Kauffman, 1991. Group C Streptococcal bacterimia: Analysis of 88 cases. Rev. Infect. Dis., 13: 270-280.

de Nys, R., J.C. Coll and I.R. Price, 1991. Chemically mediated interactions between the red alga Plocamium hamatum (Rhodophyta) and the octocoral Sinularia cruciata (Alcyonacea). Mar. Biol., 108: 315-320.

Drobniewski, F.A., 1993. Bacillus cereus and related species. Clin. Microbiol. Rev., 6: 324-338.

Edwards, A.T., M. Roulson and M.J. Ironside, 1988. A milk-borne outbreak of serious infection due to Streptococcus zooepidemicus (Lancefield group C). Epidemiol. Inf., 101: 43-51.

Madigan, M.T., J.M. Martinko, J. Parker and T.D. Brock, 2000. Biology of Microorgamisms. Prentice-Hall, Inc., New Jersey, USA.

Marahiel, M.A., T. Stachelhaus and H.D. Mootz, 1997. Modular peptide synthetases involved in nonribosomal peptide synthesis. Chem. Rev., 97: 2651-2673.

Morikawa, M., H. Daido, T. Takao, S. Murata, Y. Shimonishi and T. Imanaka, 1993. A new lipopeptide biosurfactant produced by Arthrobacter sp. Strain MIS38. J. Bacteriol., 175: 6459-6466.

Mossialos, D., U. Ochsner, C. Baysse, P. Chablain, J.P. Pirnay, N. Koedam, H. Budzikiewicz, D.U. Fernandez, M. Schafer, J. Ravel and P. Cornelis, 2002. Identification of new, conserved, nonribosomal peptide synthetases from fluorescents pseudomonads involved in the biosynthesis of siderophore pyoverdine. Mol. Microbiol., 45: 1673-1685. 
Nielsen, T.H., D. Sorensen, C. Tobiasen, J.B. Andersen, C. Christophersen, M. Givskov and J. Sorensen, 2002. Antibiotic and biosurfactant properties of cyclic lipopeptides produced by fluorescent Pseudomonas sp. from the sugar beet rhizophere. Applied Environ. Microbiol., 68: 3416-3423.

Proksch, P., R.A. Edrada and R. Ebel, 2002. Drugs from the seas-current status and microbiological implications. Applied Microbiol. Biol., 59: 125-134.

Radjasa, O.K. and A. Sabdono, 2003. Screening of secondary metabolite-producing bacteria associated with corals using $16 \mathrm{~S}$ r DNA-based approach. J. Coast. Dev., 7: 11-19.

Radjasa, O.K., T. Martens, H.P. Grossart, T. Brinkoff, A. Sabdono and M. Simon, 2007. Antagonistic activity of a marine bacterium Pseudoalteromonas luteoviolacea TAB4.2 associated with coral Acropora sp. J. Biol. Sci. (In Press).

Ramette, A., Y. Moenne-Loccoz and G. Defago, 2001. Polymorphism of the polyketide synthase gene phlD in biocontrol fluorescents pseudomonads producing 2,4-Diacetylphloroglucinol and comparison of PhlD with plant polyketide synthases MPMI., 14: 639-652.

Roongsang, N., K. Hase, M. Haruki, Tadayuki Imanaka, Masaaki Morikawa and S. Kanaya, 2003. Cloning and characterization of the gene cluster encoding arthrofactin synthetase from Pseudomonas sp. MIS38. Chem. Biol., 10: 869-880.
Salasia, S.I.O., 2001. Determination of intraspecies variations of the V2 region of the 16S rRNA gene of Streptococcus equi subsp. zooepidemicus isolated from pigs, monkeys and humans on the island of Bali Indonesia. Indon. J. Biotech., 6: 513-520.

Salasia, S.I.O., I.W.T. Wibawan, F.H. Pasaribu, A. Abdulmawjood and C. Lammler, 2004. Persistent occurrence of a single Streptococcus equi subsp. epidemicus clone in the pig and monkey population in Indonesia. J. Vet. Sci., 5: 263-265.

Sammarco, P.W. and J.C. Coll, 1992. Chemical adaptation in the Octocorallia: Evolutionary considerations. Mar. Ecol-Prog. Ser., 88: 93-104.

Sorensen, D., T.H. Nielsen, J. Sorensen and C. Christophersen, 2002. Cyclic lipoundecapeptide lokisin from Pseudomonas sp. Strain DSS41. Tetrahedron. Lett., 43: 4421-4423.

Stachelhaus, T., A. Schneider and M.A. Marahiel, 1995. Rational design of peptide antiniotics by targeted replacement of bacterial and fungal domains. Science, 269: 69-72.

Thiel, V. and J.F. Imhoff, 2003. Phylogenetic identification of bacteria with antimicrobial activities isolated from Mediterranean sponges. Biomol. Eng., 20: 421-423.

Toh, M., M.C. Moffitt, L. Henrichsen, M. Raftery, K. Barrow, J.M. Cox, C.P. Marquis and B.A. Neilan, 2004. Cereulide, the emetic toxin of Bacillus cereus, is putatively a product of non-ribosomal peptide synthesis. J. Applied Microbiol., 97: 992-1000. 